\title{
STRATEGI SEORANG GURU TERHADAP PENDIDIKAN ABAD 21 TERUTAMA PEMBELAJARAN SEJARAH
}

\author{
Akbar Hidayat \\ Email:akbarhidayat3203@gmail.com \\ Program Studi Pendidikan Sejarah Fakultas Keguruan dan Ilmu Pendidikan \\ Universitas Lambung Mangkurat \\ Banjarmasin
}

\begin{abstract}
Abstrak
Tulisan ini mendeskripsikan tentang mengapa perlunya mempelajari sebuah strategi pembelajaran sejarah, Bagaimana keterkaitan antara perencanaan pembelajaran sejarah dengan strategi pembelajaran sejarah dan Bagaimana keterkaitan model, metode, pendekatan, dan strategi pembelajaran sejarah serta teknologi dalam pembelajaran sejarah abad 21, terutama dalam pembelajaran daring pada masa pandemic COVID-19.
\end{abstract}

\section{PENDAHULUAN}

Perkembangan teknologi sekarang ini sangatlah cepat dimana teknologi tersebut dapat mempengaruhi kehidupan manusia baik dari hal kecil hingga hal yang besar terutama dalam bidang pendidikan, dengan adanya teknologi proses pendidikan dapat dimudahkannya namun bagaimana seorang guru ataupun calon guru untuk menyatukan sebuah teknologi ke sebuah strategi dalam proses pembelajarannya, strategi adalah rencana atau kebijakan yang dirancang untuk mencapai suatu tujuan, sehingga keputusan yang dibuat dalam rangka pengembangan strategi pembelajaran memerlukan pertimbangan-pertimbangan guru menyangkut fokus kurikulum, pengetahuan dan pengalaman yang akan diberikan kepada siswa, minat siswa, gaya belajar siswa, dan tingkat perkembangan siswa, yang secara keseluruhan menyangkut model pembelajaran yang dipilih oleh guru. Keputusan tersebut didasarkan pada penilaian terhadap siswa yang berkaitan juga dengan tujuan dan proses pembelajaran. Dimasa modern sekarang perlunya seorang guru untuk menyiapkan sebuah 
stategi pembelajaran terutama di pelajaran sejarah dengan berbagai strategi yang di padukan dengan teknologi yang berkembang saat ini dimana hal tersebut diharapkan membawa sebuah proses ppembelajaran yang baik dan bertujuan mencerdaskan siswa dan meningkatkan belajar mereka pada saat sekolah. Sejarah disini memiliki peran penting terhadap karakter peserta didik yang nantinya akan menjadi penerus bangsa, dimana sejarahlah yang akan memerikan pembelajaran kepada kita bagaimana yang terjadi pada masa lalu, seperti yang dikatakan bahawa Tafsiran sejarawan tentang realita masalalu direnungkan dan dicari nilainilai sehingga dapat bertatap muka dan bersapaan sebagai bagian dari interaksi dengan masa kekinian. Dapat dikatakan, bahwa Masa kekinian tidak langsung menjadi melainkan hasil dari proses masa lampau titik bahasa, historiografi atau karya sejarah dengan jiwa zamannya berperan sebagai penghubung dengan masa kekinian (Anis, 2014:481). Dan juga mencintai budaya lokal terutama yang ada di Banjarmasin, Urang Banua, sebutan untuk orang Banjar, dikaruniai banyak hasil cipta, rasa, dan karsa yang hingga sekarang masih banyak yang dilestarikan. Sebutlah misalnya adat perkawinan, sistem pengetahuan, kesenian, alat-alat bercocok tanam, bahkan bahasa lokal masih lestari dalam keseharian mereka. Hal ini menunjukkan bahwa orang Banjar masih menjaga tradisi leluhur (Jumadi, 2016:176). Karena budaya tercipta beriringan dengan sejarah masa lalu yang dihasilkan para nenek moyang terdahulu.

\section{STRATEGI PEMBELAJARAN SEORANG GURU}

Strategi pembelajaran sangatlah penting dalam proses pembelajaran namun sebelum dilaksanakan sebuah strategi pembelajaran maka yang paling utama adalah menyiapkan perencanaan pembelajaran biasanya perencanaan ini disiapkan oleh seorang guru sebelum melakukan proses pembelajaran yang gunanya untuk menjadikan proses pembelajaran tadi berjalan dengan apa yang semestinya dan sesuai target pembelajaran guru, perencanaan dari seorang guru biasanya seperti Persiapan guru saat melakukan pembelajaran adalah guru harus memikili dahulu strategi pembelajaran dimana dalam hal ini dapat memudahkan langkahlangkah guru dalam proses mengajar nanti. Dalam rencana pembelajaran nanti guru dapat mempersiapkan apa saja media pembelajaran yang dapat membantu dalam proses kegiatan 
pembelajaran dikelas, sehingga dapat menciptakan suasana yang nyaman dalam proses mengajar nanti. Dengan guru memiliki strategi pembelajaran maka guru dapat dengan mudah menyampaikan materi yang disampaikan kepada siswa sehingga siswa dapat mudah memahami apa yang disampaikan oleh guru.dan yang pasti dalam strategi ini terdapat nilai pembelajaran sejarah karena dengan sejarah para siswa dapat memahami nilai-nilai tersebut jangan sampai siswa sangat awam dengan sejarahnya hal ini sesuai dengan yang dinyatakan oleh Mohamad zainal arifin anis yang mengatakan bahwa Pandangan awam terkadang menganggap sejarah dan kesadaran sejarah mempunyai arti yang sama. Pertama yang mesti saya dahulukan, bahwa sejarah menurut para ahli adalah ilmu atau sains titik tengok saja pendapat Walsh yang menyatakan, sejarah digambarkan sebagai ilmu pengetahuan yang studinya dilakukan melalui metode (Anis, 2016:448). Hal itu juga dapat mengasah kemampuan siswa dalam berpikir kritis, berkreatif, berkerja sama dan memiliki komunikasi yang baik.

Dalam strategi pembelajaran pasti ada yang namanya sebuah model pembelajaran, metode, dan pendekatan. Diamana semua itu merupakan sebuah kesatuan dalam proses pembelajaran yang biasanya dilakukan oleh pengajar dengan strategi tersebut dapat menentukan tujuan dari sebuah pembelajaran yang di inginkan dan mendapatkan pembelajaran yang afektif dan efisien, yang dimana dalam pembelajaran dimualai melalui sebuah pendekatan dimana dengan pendekatan ini seorang guru biasanya memulai sebuah proses pembelajaran Pendekatan digambarkan sebagai kerangka umum tentang skenario yang digunakan guru untuk membelajarkan siswa dalam kerangka mencapai suatu tujuan pembelajaran. Pendekatan juga dapat diartikan sebagai titik tolak atau sudut pandang kita terhadap proses pembelajaran. Istilah tersebut menunjukan pada pandangan terjadinya proses yang sifatnya masih sangat umum. Kemudian dalam melakukan pendekatan atau memulai sebuah pembelajaran biasanya didalam pembelajaran tersebut ada yang namanya metode yang di lakukan seorang guru untuk muridnya seperti metode ceramah, metode diskusi, dan tanya jawab. Dengan metode ceramah biasanya para guru melakukan penyampaian materi dalam pembelajaran menggunakan lisan untuk menyampaikan ilmunya setelah materi disampaikan biasanya guru memberikan pertanyaan yang dimana pertanyaan 
tersebutmerupakan langkah guru untuk mengetahui sampai mana kemampuan siswa terhadap materi yang di sampaikan seorang guru, dan untuk melengkapi sebuah pembelajaran biasanya dilakukan diskusi metode diskusi ini juga alah satu cara memecahkan persoalan secara bersama-sama, dengan mengemukakan dan pertukaran pengetahuan yang ada pada guru dengan murid, sehingga akan menemukan jawaban yang tepat. Metode diskusi adalah cara yang baik untuk merangsang murid-murid berpikir dan mengeluarkan pendapat sendiri, serta ikut mengembangkan pikiran dalam satu masalah bersama. Metode diskusi ini pada umumnya akan membuat suasana kelas lebih hidup, karena siswa lebih aktif dan bersemangat Di mana setiap siswa mendapat kesempatan untuk mengemukakan pendapat mereka masingmasing. Jadi metode diskusi ini merupakan proses pembelajaran yang menyebabkan terjadinya interaksi antara guru dengan siswa dan antara siswa dengan siswa. Dalam pembelajaran Sejarah metode ini sangat bermanfaat untuk mengetahui sejauh mana ilmu yang telah diajarkan dapat dikuasai oleh siswa, dan apabila terdapat perbedaan pendapat dapat diselesaikan secara bersama-sama.

\section{PEMBELAJARAN SEJARAH ABAD 21}

Pembelajaran abad 21 merupakan suatu pembelajaran yang bercirikan learning skill, skill, dan literasi. Learning skill yaitu kegiatan pembelajaran yang di dalamnya ditandai dengan adanya kerja sama, komunikasi, serta berpikir kritis dan kreatif. Pembelajaran abad 21 atau pembelajaran kekinian, Pada masa kekinian terdapat dikotomi antara pendidikan modern dan tradisional. Anggapan umum tampaknya berpihak kepada pendidikan modern yang mampu memproduksi peradaban pada setiap zaman selalu melahirkan peradaban (Anis, 2015:224). Pembelajaran abad 21 juga bisa dikatakan sebagai sarana mempersiapkan generasi abad 21. Di mana kemajuan teknologi informasi dan komunikasi (TIK) yang berkembang begitu pesat memiliki pengaruh terhadap berbagai aspek kehidupan, termasuk pada proses belajar-mengajar. Contohnya, peserta didik diberi kesempatan dan dituntut untuk mampu mengembangkan kecakapannya dalam menguasai teknologi informasi dan komunikasi, khususnya komputer. Dengan begitu, peserta didik memiliki kemampuan dalam menggunakan teknologi pada proses pembelajaran yang bertujuan untuk mencapai kecakapan berpikir dan belajar peserta didik.). Dengan pembelajaran abad 21 ini ditujukan 
kepada siswa agar mampu berfikir secara kreatif, bekerja kreatif serta dapat mengimplementasikan sebuah inovasi dari sebuah pemikiran. Siwa juga dapat berfikir kritis dan dapat memecahkan sebuah masalah, berbicara mengenai berfikir secara kritis hal tersebut terjadi karena sejarah merupakan peristiwa yang multidimensional yang mengakibatkan siwa harus berfikir kritis terhadap sebuah pristiwa tersebut, Terlebih dalam pembelajaran sejarah, di mana setiap peristiwa cenderung bersifat multidimensional sehingga memungkinkan banyak jawaban untuk satu persoalan. Sisi positifnya, hal ini dapat memicu kemampuan berpikir tingkat tinggi peserta didik, mendorong munculnya kreativitas dan terbiasa terhadap perbedaan perspektif (Anis Dkk, 2020:178). siswa dapat menggunakan sistem berfikirnya melalui penalaran yang efektif hingga terpecahkan sebuah masalah. Yang terpenting dari pembelajaran abad 21 ini juga terletak pada kemampuan siswa mengolah sebuah informasi secara jelas dalam artian tidak sembarang menerima informasi yang didapat langsung di terima begitu saja secara mentah-mentah, dengan pembelajaran abad 21 ini siwa diharapkan mampu mengolah informasi dengan baik dan diharapkan mampu berkolaborasi dengan orang lain. Tidak hanya itu murid juga dapat mengevaluasi sebuah informasi serta menata informasi yang didapat lalu dapat menganalisisnya, dari hasil analisis tersebut akan tercipta sebuah media yang dapat di aplikasikan pada sebuah teknologi secara efektif. Dalampembelajran abad 21 ini ini juga dapat membentuk character building dimana para siswa dapat berperilaku scientific attitude yaitu hasrat ingin tahu, jujur, teliti, terbuka dan penuh kehati-hatian. Dan yang terakhir pembelajaran ini menekankan pada spiritual values dimana siswa dapat menghayati konsep ketuhanan melalu sebuah ilmu pengetahuan dan menginternalisasikan nilai-nilai spiritual dalam kehidupan sehari-hari. Hal ini merupakan sebuah pembelajran yang dibutuhkan dizaman sekarang,

Peran teknologi dalam pembelajaran sejarah abad 21 sangat lah pentinga dimana Dalam proses pembelajaran abad 21, teknologi informasi dan komunikasi merupakan alat bantu dalam upaya mencapai proses pembelajaran yang mengutamakan kemampuan keterampilan kecakapan abad 21 yang harus dimiliki oleh peserta didik. Banyak perangkatperangkat teknologi atau aplikasi-aplikasi berbasis teknologi informasi yang menunjang aktivitas siswa dalam proses pembelajaran untuk mencapai kemampuan 
kecakapan abad 21 seperti kecakapan kreativitas, inovasi, komunikasi, kolaborasi, literasi informasi dan media, dan sebagainya. Dalam pelaksanaan pembelajaran, sarana TIK dapat digunakan sebagai sarana untuk meningkatkan kreativitas siswa. Siswa dapat memanfaatkan sara-sarana teknologi informasi dan komunikasi atau aplikasi-aplikasi komputer dalam aktivias pembelajarannya seperti Teknologi Internet yang dapat dimanfaatkan siswa sebagai sumber belajar pada pembelajaran sejarah maupun yang lainnya. Dengan menggunakan teknologi internet, siswa dapat mengakses sumber-sumber belajar yang ada di dalamnya dengan memanfaatkan halaman-halaman sistus web yang menyediakan informasi-informasi yang dibutuhkan oleh siswa. Dengan teknologi internet, siswa dapat mengakses berbagai informasi yang dibutuhkan sesuai dengan materi pembelajaran yang dibahas dalam pembelajaran di sekolah, sehingga melatih kemandirian siswa dalam mencari kebutuhan informasi serta meningkatkankreativitas siswa dalam mengumpulkan informasi dari berbagai sumber yang dapat dijadikan sumber pembelajaran. Apalagi di situasi pandemic seperti ini dimana teknologi sangatlah dibutuhkan dalam berbagai bidang seperti pada pendidikan teknologi dibutuhkan agar membantu proses pembelajaran secara daring berjalan dengan baik akibat covid 19 yang awalnya sekolah dilakukan secara tatap muka namun akibat adanya pandei ini maka dilaksanakan secara online di rumah masing-masing, berkat adanya teknologi kita menjadi mudah untuk melakukan akses secara daring melalui smartphone atau computer kita dimana hal ini agar proses pembelajaran yang dilakukan berjalan dengan lancar dan tanpa hambatan walaupun sedang berada di siuasi pandemic seperti sekarang betapa bermanfaat dan sangat berguna sebuah teknologi di era sekarang dengan teknologi juga membuat para siswa mudah dalam mencari sebuah informasi yang ingin di cari dan teknologi mampu untuk meningkatkan minat belajar siswa terutama Dalam pembelajaran sejarah, ,siswa mamp mencari informasi bersejarah hanya dengan menggunakan telepon pintar mereka.

\section{SIMPULAN}

Perkembangan teknologi sekarang ini sangatlah cepat dimana teknologi tersebut dapat mempengaruhi kehidupan manusia baik dari hal kecil hingga hal yang besar terutama dalam bidang pendidikan strategi adalah rencana atau kebijakan yang dirancang untuk 
mencapai suatu tujuan, sehingga keputusan yang dibuat dalam rangka pengembangan strategi pembelajaran memerlukan pertimbangan-pertimbangan guru menyangkut fokus kurikulum, pengetahuan dan pengalaman yang akan diberikan kepada siswa, minat siswa, gaya belajar siswa, dan tingkat perkembangan siswa, yang secara keseluruhan menyangkut model pembelajaran yang dipilih oleh guru. Pembelajaran abad 21 merupakan suatu pembelajaran yang bercirikan learning skill, skill, dan literasi. Learning skill yaitu kegiatan pembelajaran yang di dalamnya ditandai dengan adanya kerja sama, komunikasi, serta berpikir kritis dan kreatif. Pembelajaran abad 21 juga bisa dikatakan sebagai sarana mempersiapkan generasi abad 21, Peran teknologi dalam pembelajaran sejarah abad 21 sangat lah pentinga dimana Dalam proses pembelajaran abad 21, teknologi informasi dan komunikasi merupakan alat bantu dalam upaya mencapai proses pembelajaran yang mengutamakan kemampuan keterampilan kecakapan abad 21 yang harus dimiliki oleh peserta didik. Banyak perangkatperangkat teknologi atau aplikasi-aplikasi berbasis teknologi informasi yang menunjang aktivitas siswa dalam proses pembelajaran

\section{REFERENSI}

Ainina, I. A. (2014). PEMANFAATAN MEDIA AUDIO VISUAL SEBAGAI SUMBER PEMBELAJARAN SEJARAH. Indonesian Journal of History education, 40-45.

Anis, M. Z. (2014). SEJARAH, PENDIDIKAN SEJARAH, DAN PENDIDIKAN KARAKTER DIALOG YANG TIDAK PERNAH DI TUNTASKAN. universitas lambung mangkurat, 477-488.

Anis, M. Z. (2015). PENDIDIKAN HUMANIORA DALAM MASYARAKAT BANJAR DI KALIMANTAN SELATAN. Dosen program studi pendidikan sejarah FKIP unlam banjarmasin, 223-242.

Anis, M. Z. (2016). sejarah, kesadaran dan pupusnya identitas nasional. Dosen Program Studi Pendidikan Sejarah FKIP Universitas Lambung Mangkurat, 487-494.

Jumadi, d. (2016). RINGKASAN HASIL-HASIL KAJIAN BUDAYA DAN SEJARAH BANJAR . Yogyakarta: Penerbit Ombak.

Mohamad Zaenal Arifi Anis, d. (2020). SISI ABU-ABU KAUSALITAS DAN EVALUASINYA DALAM PEMBELAJARAN SEJARAH. Jurnal Socius, 169-180. 
Sayono, J. (2013). PEMBELAJARAN SEJARAH DI SEKOLAH: DARI PRAGMATIS KE IDEALIS. SEJARAH DAN BUDAYA, 9-17. 